RESEARCH PAPER

\title{
From adversary to target market: the ACT-UP boycott of Philip Morris
}

\author{
N Offen, E A Smith, R E Malone
}

Tobacco Control 2003;12:203-207

See end of article for authors' affiliations

.................

Correspondence to: Naphtali Offen, Box 0612, Department of Social and Behavioural Sciences, San Francisco, San Francisco, CA 94143, USA; naph@itsa.ucsf.edu

Received 24 December 2002. Accepted 6 March 2003

\begin{abstract}
Background: In 1990, the AIDS Coalition to Unleash Power (ACT-UP) sparked a year long boycott of Philip Morris's Marlboro cigarettes and Miller beer. The boycott protested the company's support of Senator Jesse Helms (R-North Carolina), a leading opponent of AIDS funding and civil rights for lesbian, gay, bisexual and transgender (LGBT) people. ACT-UP demanded that Philip Morris sever its ties with Helms and acknowledge its responsibility to the LGBT community and to people with AIDS. Objective: To assess the impact of the boycott on the LGBT community, the tobacco industry, and the tobacco control movement; and to determine what lessons tobacco control advocates can extract from this case.

Data sources: Internal tobacco industry documents and newspaper archives.

Methods: Search of tobacco industry documents websites using "boycott", "ACT-UP", "gay", and other terms.

Results: Philip Morris used the boycott to its own advantage. It exploited differences within the community and settled the boycott by pledging large donations to combat AIDS. Through corporate philanthropy, Philip Morris gained entrée to the LGBT market without appearing gay friendly. Many LGBT organisations, thirsty for recognition and funding from mainstream corporations, welcomed Philip Morris's overtures without considering the health hazards of tobacco.

Conclusions: Unless the goal of a boycott is to convince the tobacco industry to abandon tobacco altogether, such actions invite the industry to expand its marketing under the guise of philanthropy. Tobacco control advocates should be clear about goals and acceptable settlement terms before participating in a boycott of a tobacco company.
\end{abstract}

t n April 1990, the Washington DC chapter of the AIDS Coalition to Unleash Power (ACT-UP) called for a national boycott of Philip Morris's Marlboro cigarettes. The boycott protested Philip Morris's financial support for Jesse Helms (R-North Carolina), the Senate's leading opponent of AIDS funding and civil rights for lesbian, gay, bisexual and transgender (LGBT) people. The boycott unintentionally provided Philip Morris with an opportunity to market tobacco to the LGBT community. This case study based on archival records examines Philip Morris's response to the boycott and its subsequent interaction with the LGBT community.

\section{METHODS}

Primary data for this study included internal tobacco industry documents released as a result of the 1998 Master Settlement Agreement, contemporaneous media accounts of the boycott, and ACT-UP organisational documents. Data were collected from the University of California, San Francisco Legacy Tobacco Documents Library (legacy.library.ucsf.edu), the Philip Morris Incorporated Document Website (www.pmdocs.com), the Tobacco Institute Document Site (www.tobaccoinstitute.com), and the Lorillard Tobacco Document Site (www.lorillarddocs.com) from July 2001 to August 2002. Search terms included "boycott", "ACT-UP", "gay", "Helms", and other terms suggested by the results of the primary searches. ${ }^{1}$ These searches identified a total of 45 unique documents relevant to the boycott.

We also searched 20 national and local lesbian and gay publications including the Advocate, the San Francisco Sentinel, the Windy City Times, and the Washington Blade, and eight mainstream newspapers including the New York Times, the Los Angeles Times and the Washington Post, yielding 80 articles about the boycott and its ramifications. Letters to the editor provided grass roots perspectives. Searches of the ACT-UP/New York archives at the San Francisco Public Library yielded 60 documents. These archival data were analysed using a chronologically organised descriptive case study approach. ${ }^{2}{ }^{3}$

\section{RESULTS}

\section{Background}

ACT-UP, a network of grassroots groups dedicated to pressuring the government for greater responsiveness to the AIDS epidemic, was founded in 1987 in New York City. ${ }^{4}$ ACT-UP's activities ranged from protesting discriminatory practices to advising the Food and Drug Administration. US Senator Jesse Helms, first elected to the Senate in 1972, consistently voted against the interests of the LGBT and AIDS communities, including opposing AIDS prevention materials ${ }^{5}$ and supporting mandatory HIV testing. ${ }^{6}$ Philip Morris was one of Helms's leading corporate contributors ${ }^{67}$ and by 1990 had committed $\$ 200000$ to the Jesse Helms Citizenship Center in Monroe, North Carolina. ${ }^{8}$

\section{Initiating the boycott}

On 16 April 1990, ACT-UP/Washington DC announced a boycott of Marlboro cigarettes to protest Philip Morris's contributions to Helms. ACT-UP/DC demanded that Philip Morris stop funding Helms, renounce its past support, and

Abbreviations: ACT-UP, AIDS Coalition to Unleash Power; GASP Group Against Smoking Pollution; GLAAD, Gay and Lesbian Alliance Against Defamation; HRCF, Human Rights Campaign Fund; LGBT, lesbian, gay, bisexual and transgender; NGLTF, National Gay and Lesbian Task Force; SCARC, Smoking Control Advocacy Resource Center 
meet with ACT-UP/DC representatives to discuss Philip Morris's responsibility to the lesbian and gay community and to people with AIDS.

The boycott was widely reported in the gay press and spread rapidly among ACT-UP groups and the LGBT community. ${ }^{9-11}$ As one of the community's most vociferous and powerful enemies, Helms was an easily-agreed-upon target. However, the tactic was problematic. Boycotting Philip Morris in order to harm Helms was indirect. A cigarette boycott required persuading smokers to switch brands or quit altogether, no small feat under any circumstances. Additionally, it was hard to gauge the percentage of Marlboro smokers in the community and how sympathetic they would be to a boycott. In response to these issues, ACT-UP/San Francisco called for an extension of the boycott to Miller Beer, which was wholly owned by Philip Morris. ${ }^{12}$ Miller Lite was "the beer of choice" in the gay community, ${ }^{13}{ }^{14}$ and it would likely be easier to affect sales of beer than of cigarettes.

By September 1990, the boycott had spread to more than 30 cities and 300 bars and restaurants nationwide. ${ }^{15}$ The more mainstream national gay organisations, the Human Rights Campaign Fund (HRCF) and the National Gay and Lesbian Task Force (NGLTF), endorsed the action. HRCF executive director Tim McFeeley said the boycott would educate the public about Philip Morris's "undermining the struggle for an effective strategy against AIDS and full civil rights for lesbian and gay Americans". ${ }^{16}$ Urvashi Vaid, executive director of NGLTF, thought the boycott was having an effect, noting that Philip Morris officials had recently invited NGLTF to apply for a \$10 000 to \$15000 grant. "We respectfully declined," said Vaid..$^{17}$

\section{Splits in the community}

Not every segment of the gay community was in solidarity, however. Many resented ACT-UP's calling the boycott without consulting other community leaders. ${ }^{18}$ Although the call to add Miller beer to the Marlboro boycott originated in San Francisco, even that city's LGBT community was divided over it. The San Francisco Sentinel, a gay newspaper, published an editorial called "Drink up: there's no boycott" which asked, "Why the obsession with Miller, which has proven throughout the years to be one of our better corporate friends?"19 Anger mounted against ACT-UP for targeting Miller and more LGBT organisations began to express opposition. ${ }^{20-23}$

At least one gay publication sought to exploit the boycott for personal gain. Only a few weeks into the boycott, the editor of the Philadelphia Gay News contacted Philip Morris to ask them whether "in the wake of the controversy surrounding Philip Morris in the gay community" the tobacco company would consider taking out advertising in its paper during the upcoming Gay Pride Week. ${ }^{24}$ Philip Morris evaluated the request and rejected it because of "controversial editorial environment and insufficient coverage in Philadelphia". ${ }^{25}$

\section{Philip Morris responds}

In late April 1990, Philip Morris vice president of corporate affairs Guy Smith acknowledged receiving numerous media calls about the boycott and recommended taking "as low a profile as possible". ${ }^{26}$ Philip Morris's official statement on the action said that the company was an early and generous contributor to AIDS research, that it backed Helms solely because he supported tobacco, and that it would continue to support both AIDS research and the senator. ${ }^{27}$

Philip Morris management refused to meet with ACTUP/DC before the boycott, ${ }^{7}$ but relented once the boycott was in effect. However, an initial meeting ended without resolution. ACT-UP's Michael Petrelis, one of the boycott leaders, said that "the PM people claimed they donated \$.5 million to AIDS and suggested the gay community boycott the RJ Reynolds Nabisco Corporation instead". ${ }^{10}$
ACT-UP acknowledged that Philip Morris had given a large donation to the American Foundation for AIDS Research and supported some pro-gay and lesbian candidates. ${ }^{71}$ But it argued that "Helms has caused such destruction to our community that no number of 'sympathetic' candidates receiving money from Philip Morris can undo the damage or circumvent future harm if Helms is reelected". ${ }^{11}$ Petrelis dubbed Philip Morris's giving policy "corporate schizophrenia" akin to simultaneously supporting the National Association for the Advancement of Colored People and the Ku Klux Klan.

Despite its "low profile", Philip Morris took the boycott seriously. On 17 July 1990, vice chairman of Philip Morris Corporation RW Murray wrote, "ACT UP hurting Miller". ${ }^{28}$ The public affairs manager for Miller Brewing Company said that company representatives were visiting cities where the beer boycott was being discussed. She added: "We are always concerned when one of our consumer groups says it will stop drinking our product."29 In a speech at a corporate conference, Philip Morris Companies president John Murphy said: “Miller distributors are calling up and saying: "What the hell is your cigarette company doing to us?' It's hit some Miller Lite distributors' sales by 20 percent."'14 Meanwhile, Philip Morris's media relations staff was attending ACT-UP demonstrations to obtain ACT-UP statements and printed material. ${ }^{30}$

Vice president Guy Smith sent a letter to all major gay publications emphasising Philip Morris's support for the gay community. ${ }^{31}$ Gay Community News of Boston ${ }^{32}$ and the Windy City Times of Chicago ${ }^{33}$ were among the few to publish the letter. In his appeal, Smith reiterated that company support for Helms was strictly a business decision and called ACT-UP an "extremist group claiming to represent the entire gay community". He boasted that "Philip Morris supports legislation to make it illegal for an employer to discriminate against current or prospective employees because of avocational activities", ${ }^{32}$ implying a link between LGBT civil rights and a right to smoke.

\section{Boycotters' protest}

On 8 October 1990, Philip Morris inaugurated a nationwide company sponsored tour of a 200 year old copy of the Bill of Rights in Barre, Vermont. ACT-UP often had a loud presence at the tour stops. Protesters pointed out that Philip Morris's sponsorship of the tour conflicted with its support for Jesse Helms, well known for his opposition to the civil rights of gays. ${ }^{9}$ At the 10 December exhibit in Baltimore, boycott leader Petrelis asked, "How can a company wrap itself in the Bill of Rights at the same time it supports a man who wants to dismantle constitutional underpinnings?" ${ }^{\prime 34}$

Philip Morris spokeswoman Taggarty Patrick framed the demonstrations as "the Bill of Rights in action",' relegating the protesters to the role of bit players on Philip Morris's stage. However, at the Seattle protest on 13 July 1991, Gay Community News reported that "one portion of the exhibit, which provided visitors an opportunity to stand on a soap box and videotape themselves exercising their freedom of speech, was closed down after activists used it as an opportunity to voice their complaints about Philip Morris and Helms". ${ }^{35}$ Apparently, seeing "the Bill of Rights in action" had its limits.

The Bill of Rights tour protests were among the few occasions when ACT-UP demonstrators interacted with tobacco control activists, notably the Smoking Control Advocacy Resource Center (SCARC) and the Group Against Smoking Pollution (GASP), ${ }^{34}$ which raised the health issue in the media. SCARC sent out a press release announcing the ACT-UP boycott in which it conceded ACT-UP's motivations were political rather than health related, but noted that although "inspired by different causes, they face a common enemy". ${ }^{36}$

\section{Boycott settlement}

On 29 May 1991, after a series of meetings with Philip Morris, ACT-UP/DC and HRCF announced the boycott was over. ${ }^{37}$ The 
demand that Philip Morris drop its ties to Jesse Helms was abandoned. Instead, Philip Morris pledged to make substantial donations to AIDS related causes "throughout the epidemic's duration" ${ }^{37}$ The dollar amount remained publicly unspecified, because Philip Morris officials refused to provide details, or even put the settlement on its own letterhead. ${ }^{37}$ Petrelis of ACT-UP/DC was satisfied. "We had an ethical choice. Either we remain politically correct and continue the boycott, or settle and actually do something ... .Let's use the money to keep our friends alive." ${ }^{37}$ In response to the settlement, David Eng of the Gay Men's Health Crisis defended taking money from Philip Morris (and RJ Reynolds) because, he said, "It's important that money gets to AIDS programs and services that are in desperate need". ${ }^{37}$

However, many of the principal organisers opposed ending the boycott. ACT-UP/SF vowed to continue "until the huge conglomerate cuts off all support to Senator Helms". ${ }^{37}$ The group wanted Petrelis to pressure Philip Morris for a stand against Bush administration plans to bar people with HIV infection from immigrating to America, but was rebuffed. ${ }^{37}$ Bill Dobbs, of ACT-UP/NY, objected that "seventy groups endorsed the boycott, and only two groups ... signed on to the agreement" ${ }^{38}$

ACT-UP/SF and other challengers questioned the morality of taking money from tobacco interests. "This settlement . . represents us taking money from walking over the bodies of those killed by cigarettes," Dobbs argued. "I would characterize this as a pact with the devil." ${ }^{37}$ As the founder of a tobacco control group, Fags Against Fags, Dobbs asked: "What are we telling ... [cancer activists] if we take money from a company that causes cancer?" ${ }^{\prime 38}$

Critics also pointed out that the settlement was not much of a concession from Philip Morris. "The underlying reason for the boycott, support for the Senator and the legacy to honor this bigot, seems to be untouched," said NGLTF's Vaid. ${ }^{37}$ Dobbs characterised the promised money as "a few tax-deductible crumbs off Philip Morris's very well-stacked table". ${ }^{37}$

Settling the boycott was a public relations strategy for Philip Morris, not a financial defeat. According to Rebecca Barfield, a tobacco industry analyst for First Boston Corp: "The boycott had little effect on the firm's stock prices or earnings, but the company was eager to come to terms with the activists because it worries about its public image." ${ }^{39}$

\section{DISCUSSION}

Measuring the success of this boycott depends on the yardstick used. Among the boycotters themselves, there was little consensus about the outcome. The most significant long term consequence, the emergence of Philip Morris as a major corporate player in the LGBT and AIDS communities, was almost assuredly unintended, at least from the perspective of the boycott organisers. However, it offers a valuable lesson for the tobacco control movement.

In some ways, the boycott proved problematic for the LGBT and AIDS communities. The manner in which ACT-UP called the boycott, without consulting the larger community, remained a source of friction throughout its duration. Extending the boycott to Miller beer was controversial, especially among groups sponsored by Miller. However, the boycott generated a great deal of media coverage ${ }^{40}$ which focused national attention on the escalating AIDS crisis and the struggle for LGBT civil rights.

The boycott's settlement also had mixed consequences for the LGBT and AIDS communities. Millions of sorely needed dollars were funnelled to AIDS organisations. ${ }^{37}$ Miller beer increased its support for the community, by buying more advertising in the LGBT press, ${ }^{41-44}$ and testifying in support of gay and lesbian workplace anti-discrimination bills in California ${ }^{45}$ and Illinois. ${ }^{46}$ Garnering such support was a stated goal of the boycott, thinly veiled as "corporate responsibility to the lesbian and gay community and to people with AIDS". ${ }^{7}$ This demand was unpublicised throughout the course of the year long boycott, but figured prominently in the settlement. ${ }^{37}$ Thus, the boycott was at least partially successful.

However, the primary purpose of the boycott-to pressure Philip Morris to dissociate itself from Jesse Helms-was not achieved. Philip Morris never wavered from its support for Helms, ${ }^{37}$ who was re-elected and whose opposition to the interests of the LGBT and AIDS communities did not diminish throughout the 1990s.

At no time did the boycott present a threat to company earnings. Philip Morris referred to it as a "minor skirmish". ${ }^{31}$ Notwithstanding claims to the contrary, ${ }^{14}$ the impact on sales was apparently negligible: one memo estimated a loss of 5000 cases of beer a week and no measurable impact on cigarettes. ${ }^{31}$

The boycott's most significant legacy was providing Philip Morris entrée for its tobacco products into an emerging market. Miller Beer, like other alcohol companies, had supported the LGBT community at a time when many industries, including tobacco, remained skittish about doing so. Perhaps the tobacco industry, whose brands derived their popularity from carefully crafted and potentially fragile images, feared jeopardising the reputation of these brands if they were in any way associated with the gay market. ${ }^{47}$ The phenomenal success of Marlboro, with its hypermasculine aura, had to be protected.

By the early 1990s, even though the LGBT community had made remarkable progress in its quest to shed its negative image, Philip Morris remained wary of openly courting LGBTs, fearing a backlash from conservatives who still viewed homosexuality as tainted. ${ }^{47}$ ACT-UP's demand that Philip Morris fund the fight against AIDS presented the company with a less controversial portal to the LGBT market. ACT-UP's membership was overwhelmingly LGBT, and funding AIDS related causes was a way to approach the LGBT market without being overtly gay friendly.

The boycott provided Philip Morris (and eventually other tobacco companies) with an opportunity to normalise relations with the LGBT community. Indeed, while the boycott was still in progress, a consultant for Philip Morris produced a marketing plan focused on the psyches of twenty-somethings, the "generation ... behind such social action groups as ACTUP" ${ }^{48}$ In 1991, shortly after the boycott was settled, Philip Morris donated $\$ 10000$ to the Gay and Lesbian Alliance Against Defamation (GLAAD) ${ }^{49}$ In 1992, Philip Morris's first cigarette ads appeared in a gay publication. ${ }^{47}$ GLAAD applauded the move, saying, "they're recognizing the power, and the clout and the importance of the gay and lesbian community". ${ }^{50}$ By 1994, Philip Morris was conducting marketing focus groups with gay men. ${ }^{51}{ }^{52}$ With the acceleration of its charitable giving to a wide variety of LGBT and AIDS organisations, ${ }^{385} 54$ sparked by the boycott's settlement, Philip Morris established itself as a benefactor whose interests had to be considered. This is the boycott's principal legacy.

\section{Impact on tobacco control}

A few tobacco control groups such as SCARC and GASP were excited that ACT-UP focused negative attention on Philip Morris, and they were happy to ally themselves against their common adversary. The "Bill of Rights" tour provided the perfect opportunity for the health groups to inject their message into the debate. ${ }^{94} 3555$ The tobacco control groups acknowledged that they and ACT-UP had different agendas, but seemed pleased at the opportunity to join forces against Philip Morris, however long it would last. Perhaps they reasoned that anything that cast the industry in a bad light was good for tobacco control.

However, although the boycott was instigated by an organisation whose raison d'être was to fight for health, at no time 
was the issue of tobacco's health hazards raised in any significant manner by boycott organisers. Only when they expressed their opposition to the settlement did some boycott leaders argue that it was immoral to accept money from the tobacco industry. ${ }^{37}{ }^{38}$ Otherwise, the health issue rarely surfaced. ${ }^{19}$

The boycott's settlement ended any gains the boycott might have brought to the tobacco control movement. In addition to creating legitimacy and fostering dependence on industry largesse, tobacco company donations silence opposition..$^{56}$ In a 1992 memo discussing questions raised at previous shareholder meetings, one Philip Morris vice president noted ACTUP's past criticisms of the company and added: "Considering that we met with them in May and agreed to donate $\$ 1,200,000$ to AIDS-related organizations, they may decide not to raise the topic again."${ }^{57}$ Indeed, we were unable to find reports of any subsequent ACT-UP protests against Philip Morris in the tobacco documents nor in a hand search of the Advocate, a leading national gay publication.

Had the larger tobacco control movement been persuaded to endorse the boycott, perhaps in exchange for a role in negotiating a settlement, the boycott might have been more widespread and the health issues related to tobacco might have been better addressed. We can only speculate about why this did not happen. ACT-UP's lack of a central structure, the political nature of the boycott, and the prospect of an alliance with the marginalised LGBT community may all have kept health advocates at bay.

\section{Conclusion}

Although the boycott was intended as an adversarial act against Philip Morris, ultimately it became the means by which a new relationship was forged between LGBTs and the tobacco industry. The boycott drew Philip Morris's attention to the presence of a large, organised community whose members used Philip Morris tobacco and invited the company to negotiate. Although boycotters disagreed about the immediate success of the action, none apparently considered its long term impact. By forcing the company to acknowledge the community's economic and political power at a time when other mainstream companies were also beginning to advertise to LGBTs, ACT-UP encouraged Philip Morris to regard the community as a market. It was not long after the boycott was concluded that Philip Morris, and then other tobacco companies, began to advertise in the LGBT press ${ }^{47}$ and sponsor community events, following the path they took to win over the African American community. ${ }^{56}$

What makes this turn of events particularly chilling is that it occurred in the 1990s. The industry began its incursions into the African American community in the 1940s, ${ }^{58}$ long before the emergence of a scientific consensus that tobacco use was a serious health risk. ${ }^{59}$ Philip Morris's courtship of LGBTs began well after that consensus was established. ${ }^{60}$ Despite that knowledge, tobacco industry overtures provoked little discussion about tobacco related hazards in a community preoccupied with AIDS, homophobia, and anti-LGBT violence. Only a handful of LGBTs argued that the community ought to be concerned about smoking and industry influence. ${ }^{61}$ In this environment, the tobacco industry managed to establish a substantial presence in the community. The political and ethical consequences of accepting tobacco money have only recently become a matter of discussion in the LGBT community. ${ }^{62}{ }^{63}$

The results of ACT-UP's boycott demonstrate how adept the tobacco industry is at turning opposition to its own advantage. Tobacco control efforts were not served by this politically motivated action and were likely harmed when Philip Morris's influence in the LGBT community became more firmly entrenched. Unless the goal of a boycott is to convince the tobacco industry to abandon tobacco altogether, such actions provide an opportunity for the industry to expand its marketing under the guise of philanthropy.

\section{What this paper adds}

In the early 1990s, Philip Morris found itself the target of a politically motivated boycott by the AIDS group ACT-UP. By using the boycott to its advantage, Philip Morris was able to gain a foothold in the emerging gay market. Not long after the settlement, Philip Morris began to advertise in the gay press, conduct focus groups with gay men, and recruit industry allies among gay and lesbian organisations. Other tobacco companies followed suit.

Little research has been conducted on how the tobacco industry has interacted with the gay and lesbian community and no research has looked at this seminal event. In addition, no previous studies have examined the results of boycotts against the tobacco industry. This case study examines Philip Morris's progression from mild annoyance at a public relations headache to enthusiasm for an opportunity for market growth. Evidence suggests that, unless very carefully planned, boycotts may not be an effective tool against the industry and may be counterproductive.

When deciding whether to participate in a boycott, tobacco control activists should consider whether: (1) the goals and demands of the boycott are compatible with or related to tobacco control; (2) there is agreement about what settlement terms are non-negotiable; and (3) there is a viable process of negotiating and approving a settlement. Boycotts can be useful tools in calling attention to issues, including tobacco control issues. However, as this case study illustrates, careful advance planning and sustained organisational cohesiveness are needed to avoid creating unintended opportunities for the tobacco industry.

\section{ACKNOWLEDGEMENTS}

This study was supported by the National Cancer Institute, grant 1R01CA090789-01.

\section{Authors' affiliations}

N Offen, E A Smith, R E Malone, University of California, San

Francisco, San Francisco, California, USA

\section{REFERENCES}

1 Malone RE, Balbach ED. Tobacco industry documents: treasure trove or quagmire? Tobacco Control 2000;9:334-8.

2 Hill MR. Archival strategies and techniques. Newbury Park, California Sage Publications, 1993

3 Yin RK. Case study research design and methods. Thousand Oaks, California: Sage Publications, 1994.

4 Crimp D, Rolston A. AIDS DEMOgraphics. Seattle: Bay Press, 1990:27.

5 Zonana V. Did AIDS protest go too far? Los Angeles Times 1990 July $2 ; 3$.

6 ACT-UP/DC. Help stop the deadly Helms agenda! Philip Morris. April 1990. Access date: 30 November 2001. Bates No. 2024262559. URL: http://legacy.library.ucsf.edu/tid/vmi85e00.

7 ACT-UP/DC. AIDS activists announce boycott of Marlboro cigarettes. Philip Morris. 16 April 1990. Access date: 23 July 2001. Bates No. 2024262561/2563. URL: http://legacy.library.ucsf.edu/tid/fxi85e00

8 Rothstein M. Uneasy partners: arts and Philip Morris. Philip Morris. 18 December 1990. Access date: 26 February 2002. Bates No. $2046019116 / 9119$. URL: http://legacy.library.ucsf.edu/tid/zki48d00

9 Bull C. Philip Morris tour is the new target for Helms's foes. Advocate 1991 January 15:14-15.

10 DeRanleau M. Boycott Marlboro!! San Francisco Sentinel 1990 April $26 ; 1,6$

11 Keen LM. ACT-UP/DC calls for boycott of Philip Morris. Philip Morris. 20 April 1990. Access date: 26 November 2001. Bates No. 2024262557. URL: http://legacy.library.ucsf.edu/tid/tmi85e00

12 Nealon C. Anti-Jesse Helms boycotts gain momentum. Gay Community News 1990 September 2-8;1,7

13 Solomon N. ACT-UP responds to boycott skeptics. San Francisco Sentinel 1990 August 9;9.

14 Murphy J. Working together. Philip Morris. 13 September 1990. Access date: 23 July 2001. Bates No. 2025426610/6620. URL: http://legacy.library.ucsf.edu/tid/yuq25e00 
15 Hollingsworth G. Despite mixed reactions, Miller boycott spreads. Advocate 1990 September 25;58

16 Schmitz S. HRCF joins boycott. Gay Community News 1990 September 9-15;2.

17 Nealon C. National gay groups endorse Marlboro/Miller boycott. Gay Community News 1990 November 3-9;2.

18 Vollmer T. Learning the basics of community activism. San Francisco Sentinel 1990 August 9;9.

19 Chalker R. Drink up: there's no boycott. San Francisco Sentinel 1990 August 2;9.

20 Bradford R. Boycott of Miller Beer. San Francisco Sentinel 1990 August $9 ; 8$

21 Boyd SW. Tavern Support. San Francisco Sentinel 1990 August 23;8.

22 Voight M. Golden Brands' Helping Hands. San Francisco Sentinel 1990 August 30;8.

23 Editor. Miller Beer boycott a mistake. Windy City Times 1990 August $23 ; 11$.

24 White A. [Summary of media calls May, 1990]. Philip Morris. 29 May 1990. Access date: 9 September 2001. Bates No. 2025891797/1806. URL: http://legacy.library.ucsf.edu/tid/ide95e00

25 Philip Morris. Philip Morris media: new media opportunities. Philip Morris. 22 June 1990. Access date: 2 August 2002. Bates No. 2041794248/4308. URL: http://legacy.library.ucsf.edu/tid/krk76e00

26 Smith IV GL. Helms/ACT-UP statement. Philip Morris. 24 April 1990. Access date: 23 July 2001. Bates No. 2024262552. URL http://legacy.library.ucsf.edu/tid/nxi85e00

27 Philips Morris, Statement re: Senator Jesse Helms/ACT-UP complaint. Philip Morris. April 1990. Access date: 23 July 2001. Bates No. 2024262555. URL: http://legacy.library.ucsf.edu/tid/rmi85e00

28 Philip Morris. Accommodation. Philip Morris. 17 July 1990. Access date: 23 July 2001. Bates No. 2048302288/2292. URL: http://legacy.library.ucsf.edu/tid/mos65e00

29 Anon. Bar owners agree not to reorder Miller. San Francisco Sentinel 1990 July $26 ; 2$.

30 Philip Morris. Media relations activities report - August 1990. Philip Morris. August 1990. Access date: 20 July 2001. Bates No. 20473 19328. URL: http://legacy.library.ucsf.edu/tid/fuu66e00

31 Smith IV GL. [PM August 1990 report]. Philip Morris. 7 September 1990. Access date: 23 July 2001. Bates No. $2021198897 / 8900$. URL: http://legacy.library.ucsf.edu/tid/wil46e00

32 Smith IV GL. Philip Morris speaks out on Helms/ACT UP controversy. Gay Community News 1990 September 16-22;5

33 Smith IV GL. Philip Morris justifies support of Helms. Windy City Times 1990 September 13;10.

34 Zeh J. Baltimore activists decry Philip Morris exhibit. Gay Community News 1990 December 16-22;3

35 Smith Yang J. Activists disrupt Philip Morris exhibit. Gay Community News 1991 July 21-27;3

36 Advocacy Institute - Smoking Control Advocacy Resource Center (SCARC). Action Alert, Issue: AIDS groups call for Marlboro boycott. Lorillard. 24 August 1990. Access date: 26 December 2001. Bates No. 87646854/6855. URL: http://legacy.library.ucsf.edu/tid/cvs2 le00

37 Zeh J. Activists split on ending Philip Morris boycott. San Francisco Sentinel 1991 June 6:5,10.

38 Yukins E. Is the Miller/Marlboro boycott over? Gay Community News 1991 June $2-8 ; 1,6$.

39 Anon. The money is a drop in the bucket for Philip Morris. Advocate 1991 July 2;30.

40 Nealon C. Vermont activists disrupt Philip Morris exhibit. Gay Community News 1990 October 27-November 2;3, 13

41 Anon. [Miller beer full page ad]. San Francisco Sentinel 1991 May $23 ; 6$.

42 Anon. Rainbows for relief. San Francisco Sentinel 1991 November
43 Anon. Meet Ray's challenge: "rainbows for relief" to raise more than $\$ 10,000 "$. San Francisco Sentinel 1992 May 4;6.

44 Anon. [Miller beer full page ad]. San Francisco Sentinel 1992 May $4: 51$.

45 Anon. Miller Brewing Co. to testify in favor of California gay rights bill, AB 2601. San Francisco Sentinel 1992 April 23;8.

46 Anon. Miller Brewing Company supports Illinois gay rights bill. San Francisco Sentinel 1993 May 19;16.

47 Smith EA, Malone R. The outing of Philip Morris: advertising tobacco to gay men. Am J Public Health (in press).

48 AT [Armando Testa Advertising]. Philip Morris Battistoni creative presentation. Philip Morris. 15 March 1991. Access date: 23 July 2001. Bates No. 2023045074/5111. URL: http://legacy.library.ucsf.edu/tid/ avx25e00

49 Wolfe SM, Public Citizen Health Research Group. Internal documents detail aggressive tobacco industry campaign. Philip Morris. January 1993. Access date: 7 November 2001. Bates No. 2047896864/6867. URL: http://legacy.library.ucsf.edu/tid/soz42e00

50 Philip Morris. Video Monitoring Services of America. Good Day New York. 17 August 1992. Access date: 20 July 2001. Bates No. 2023439140/9141. URL: http://legacy.library.ucsf.edu/tid/pgq98e00

51 Rodriguez Y. B\&H qualitative research in San Francisco - Final report. Philip Morris. 28 February 1994. Access date: 2 January 2002. Bates No. $2040711701 / 1702$. URL: http://legacy.library.ucsf.edu/tid/ pvf66e00

52 Guiles \& Associates. P.M.I. development: Triad topic guide. Philip Morris. 25 January 1994. Access date: 2 January 2002. Bates No. 2047264549/4551. URL: http://legacy.library.ucsf.edu/tid/ibs26e00

53 Philip Morris. AIDS does not discriminate. Philip Morris. 1999. Access date: 2 August 2002. Bates No. 2072364511/4512. URL: http://legacy.library.ucsf.edu/tid/amy28d00.

54 California Lavender Smokefree Project. Tobacco sponsorship - is the industry money worth it? The Smokefree Sentinel. San Francisco, 1999: 1

55 Cohen P. And in Rhode Island. Gay Community News 1990 October 27-November 2;3.

56 Yerger VB, Malone, R.E. African American leadership groups: smoking with the enemy. Tobacco Control 2002;11:336-45.

57 Bartlett D. Q\&As at 1990 and 1991 shareholders meetings. Philip Morris. 16 April 1992. Access date: 24 July 2001. Bates No. 20228493 18. URL: http://legacy.library.ucsf.edu/tid/lpu34e00

58 US Department of Health and Human Services. Tobacco use among U.S. racial/ethnic minority groups: African Americans, American Indians and Alaska Natives, Asian Americans and Pacific Islanders, Hispanics. A report of the Surgeon General, 1998. Atlanta, Georgia: Centers for Disease Control and Prevention, Office on Smoking and Health, 1998. (US Government Printing Office Publication No S/N 017-001-00527-4.)

59 US Department of Health, Education, and Welfare. Smoking and health. Report of the Advisory Committee to the Surgeon General of the Public Health Service. Washington, DC: Public Health Service, 1964: 387. (PHS Publication No. 1103.)

60 Goebel K. Lesbians and gays face tobacco targeting. Tobacco Control 1994;3:65-7

61 Offen N. Gays and lesbians against smoking. San Francisco Sentinel 1991 December 26;11.

62 Drabble L. Alcohol, tobacco, and pharmaceutical industry funding: considerations for organizations servicing lesbian, gay, bisexual, and transgender communities. Journal of Gay \& Lesbian Social Services 2000;11:1-26.

63 Drabble L. Ethical funding for lesbian, gay, bisexual, transgender \& HIV/AIDS community-based organizations: practical guidelines when considering tobacco, alcohol, and pharmaceutical funding. San Francisco: Coalition of Lavender Americans on Smoking and Health and Progressive Research and Training for Action, 2001. 